\title{
PENGGUNAAN GENTENG KERAMIK SEBAGAI PENGGANTI AGREGAT KASAR DAN ABU TERBANG SEBAGAI PENGISI PADA LASTON AC-BC
}

\author{
Kevin Doan Panjaitan ${ }^{1}$, Tan Lie Ing ${ }^{2}$ \\ ${ }^{1}$ Alumni, Program Studi Teknik Sipil, Fakultas Teknik, Universitas Kristen Maranatha \\ ${ }^{2}$ Dosen Tetap, Program Studi Teknik Sipil, Fakultas Teknik, Universitas Kristen Maranatha \\ Jalan Prof. drg. Suria Sumantri, MPH. No. 65 Bandung 40164 \\ Email: lieing.tan@yahoo.com
}

\begin{abstract}
ABSTRAK
Penggunaan limbah menjadi salah satu pokok bahasan para ahli untuk mengurangi jumlah material alam yang digunakan serta memanfaatkan limbah sebagai bahan daur ulang. Menggunakan material pengganti pada campuran beton aspal memungkinkan mutu perkerasan lentur memiliki stabilitas tinggi dan daya tahan lama, atau mungkin sebaliknya. Oleh karena itu penelitian ini bertujuan mengevaluasi pengaruh penggunaan limbah genteng keramik sebagai pengganti pada agregat kasar dan abu terbang sebagai pengisi pada campuran laston lapis pengikat (AC-BC). Dalam penelitian ini digunakan lima jenis persentase campuran agregat kasar yang berbeda, yaitu $100 \%$ kerikil; $25 \%$ kerikil dan 75\% genteng keramik; 50\% kerikil dan 50\% genteng keramik; $75 \%$ kerikil dan 25\% genteng keramik; serta 100\% genteng keramik. Pengujian dilakukan dengan alat Marshall. Nilai kadar aspal optimum (KAO) diperoleh sebesar 6,75\%. Berdasarkan hasil pengujian pada kadar aspal optimum dari kelima jenis campuran agregat kasar, penggunaan limbah genteng keramik tidak disarankan.
\end{abstract}

Kata Kunci: laston AC-BC, abu terbang, genteng keramik, stabilitas, pelelehan.

\begin{abstract}
The use of waste becomes one of the main discussion of the experts to reduce the amount of natural material used as well as to use the waste as recycling material. Utilizing substitute material in asphalt concrete mixture enables the quality of the flexible pavement to own high stability and durability, or vice versa. Therefore this research aims to evaluate the effect of the use of ceramic tile waste as substitute on coarse aggregate and fly ash as the filler on the mixture of asphalt concrete-binder course $(A C-B C)$. In this research five different types of ceramic in coarse aggregate mixture percentage, which is $100 \%$ gravel; $25 \%$ gravel and $75 \%$ ceramic tile; $50 \%$ gravel and $50 \%$ ceramic tile; $75 \%$ gravel and 25\% ceramic tile; as well as $100 \%$ ceramic tile. The examination is performed with Marshall test. The value of optimum asphalt content is 6.75\%. Based on the examination of optimum asphalt content of the five types of coarse aggregate mixture, the use of ceramic tile is not recommended.
\end{abstract}

Keywords: asphalt concrete-binder course, fly ash, ceramic tile, stability, flow.

\section{PENDAHULUAN}

Jalan merupakan prasarana transportasi yang memiliki peran penting dalam pertumbuhan perekonomian suatu negara. Seiring pertumbuhan perekonomian menyebabkan peningkatan pergerakan. Hal ini menyebabkan prasarana transportasi yang ada harus mampu menahan beban lalu lintas yang melewatinya. Perkerasan jalan yang

Penggunaan Genteng Keramik Sebagai Pengganti Agregat Kasar Dan Abu Terbang 
umum digunakan di Indonesia adalah campuran Lapis Beton Aspal (Laston) atau Asphalt Concrete (AC).

Campuran beton aspal adalah suatu lapisan permukaan yang terdiri atas campuran aspal keras dan agregat bergradasi menerus, dicampur, dihampar, dan dipadatkan dalam keadaan panas pada temperatur tertentu (Saodang, 2005). Beton aspal terbagi atas tiga jenis, yaitu: beton aspal lapis aus (AC-WC), beton aspal lapis pengikat (AC-BC), dan beton aspal lapis fondasi (AC-Base). Lapis beton aspal sebagai lapis pengikat atau AC$\mathrm{BC}$ merupakan bagian lapis permukaan di antara lapis fondasi (base course) dengan lapis aus (wearing course) yang bergradasi agregat gabungan rapat/menerus, umumnya digunakan untuk jalan-jalan dengan beban lalu lintas cukup berat (Sukirman, 2008).

Pemanfaatan limbah menjadi salah satu pokok bahasan para ahli untuk mengurangi jumlah material alam yang digunakan serta memanfaatkan limbah sebagai bahan daur ulang. Penggunaan batu bara sebagai sumber energi maka abu terbang (fly ash) dan bottom ash terdapat dalam jumlah cukup besar, sehingga memerlukan pengelolaan agar tidak menimbulkan masalah lingkungan, seperti: pencemaran udara, pencemaran perairan, dan penurunan kualitas ekosistem. Hingga saat ini pemanfaatan limbah abu terbang dalam bidang keteknik-sipilan telah banyak dilakukan, namun terus dikembangkan hingga memperoleh penggunaan limbah yang terbaik untuk dapat digunakan dalam campuran pada perkerasan lentur. Penggunaan abu terbang sebagai pengganti portland cement karena memiliki sifat pozolanik, sebagai bahan dasar batu bata dan batako dalam konstruksi rumah, sebagai bahan campuran dalam beton ringan, sebagai bahan timbunan (embankment) atau bahan perkuatan, dan sebagai stabilisasi tanah pada tanah lunak. Pemanfaatan abu terbang perlu dioptimumkan agar dapat membantu pemerintah mengatasi dampak pencemaran lingkungan serta dapat menjadi tambahan sumber penghasilan dan devisa negara.

Bahan limbah lainnya yang dapat digunakan adalah pecahan genteng. Awal ditemukannya atap genteng tanah liat (roof tile) adalah dari China, selama Zaman Neolitikum, dimulai sekitar 10.000SM, dan Timur Tengah beberapa waktu kemudian. Dari wilayah ini, penggunaan genteng tanah liat tersebar ke seluruh Asia dan Eropa. Genteng terbagi dalam beberapa jenis, antara lain: genteng keramik, genteng beton, genteng baja, genteng aspal, genteng polikarbonat, genteng sirap, dan asbes (fiber semen). Pecahan genteng yang digunakan dalam penelitian ini adalah pecahan genteng keramik. Keunggulan genteng keramik adalah harganya murah, ringan, dan tahan terhadap perubahan cuaca. Kekurangannya adalah kualitas temperatur pembakaran mempengaruhi daya serap air, kekuatan, serta umur genteng tersebut (Adnan, 2003). 
Penelitian tentang agregat pengganti untuk campuran pada perkerasan lentur telah dilakukan mengingat banyaknya material yang memungkinkan untuk digunakan. Menggunakan material lain seperti genteng keramik sebagai pengganti agregat kasar memungkinkan perkerasan lentur memiliki stabilitas tinggi dan daya tahan yang lebih lama, namun dapat juga sebaliknya. Oleh karena itu dalam penelitian ini akan dievaluasi pengaruh penggunaan genteng keramiki sebagai pengganti agregat kasar dan abu terbang sebagai pengisi pada laston AC-BC.

\section{PERKERASAN LENTUR}

Konstruksi perkerasan lentur terdiri atas lapisan-lapisan yang diletakkan di atas tanah dasar yang telah dipadatkan. Lapisan-lapisan tersebut berfungsi untuk menerima beban lalu lintas dan menyebarkannya ke lapisan di bawahnya. Perkerasan lentur terdiri atas beberapa lapisan, yaitu:

1. Lapisan Permukaan (Surface Course);

2. Lapisan Fondasi (Base Course);

3. Lapisan Fondasi Bawah (Subbase Course);

4. Lapisan Tanah Dasar (Subgrade).

Konstruksi perkerasan lentur dapat dilihat pada Gambar 2.1.

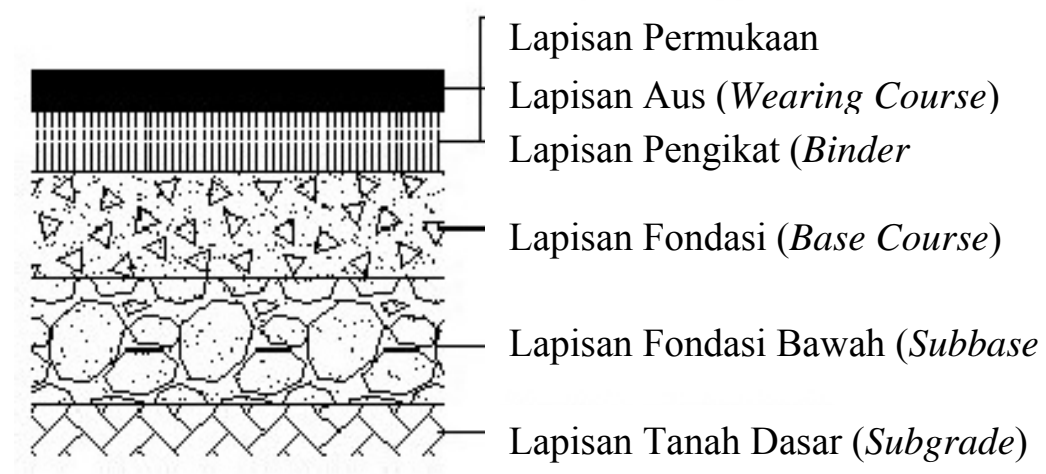

Gambar 2.1 Konstruksi Perkerasan Lentur

Lapisan permukaan pada perkerasan lentur adalah lapisan pertama yang akan menerima beban langsung dari muatan kendaraan, gaya rem kendaraan, dan getarangetaran yang berasal dari roda kendaraan. Lapisan permukaan harus mampu menerima seluruh jenis gaya yang bekerja karena sifat penyebaran gaya yang semakin kecil kesetiap lapisan di bawahnya. Lapisan permukaan memiliki fungsi sebagai lapisan penahan beban 
roda, sebagai lapisan kedap air sehingga air hujan yang jatuh tidak meresap dan merusak lapisan bawahnya, lapisan aus (wearing course) yang menahan gaya gesekan rem kendaraan, dan sebagai lapisan yang menyebarkan beban ke lapisan di bawahnya sehingga beban yang disebar dapat ditanggung oleh lapisan lainnya yang memiliki daya dukung lebih rendah.

Lapisan fondasi (base course) merupakan lapisan yang berfungsi untuk menahan gaya lintang dari beban roda dalam menyebarkan beban ke lapisan di bawahnya. Lapisan ini juga merupakan lapisan yang berfungsi sebagai lapisan resapan untuk lapisan fondasi bawah. Lapisan fondasi bawah (subbase course) merupakan lapisan yang menyalurkan beban roda ke tanah dasar. Pada penggunaan materialnya, lapisan ini merupakan lapisan termurah dan paling tebal karena diharapkan dapat mengurangi tebal lapisan di atasnya yang lebih mahal. Lapisan ini merupakan lapisan penyerapan air dari lapisan fondasi sehingga air tanah tidak berkumpul di lapisan fondasi.

Beberapa jenis lapis permukaan jalan, yaitu: Lapis Beton Aspal (Laston), Lapis Penetrasi Makadam (Lapen), Lapis Asbuton Campuran Dingin (Lasbutag), Hot Rolled Asphalt (HRA), Laburan Aspal (Buras), Laburan Batu Satu Lapis (Burtu), Laburan Batu Dua Lapis, Lapis Tipis Beton Aspal (Lataston), dan Lapis Tipis Aspal Pasir (Latasir).

\subsection{Lapis Beton Aspal (Laston)}

Beton aspal terbagi atas tiga jenis, yaitu:

1. Laston lapis aus atau dikenal dengan nama Asphalt Concrete-Wearing Course (ACWC), merupakan lapisan yang terletak di posisi paling atas. Fungsi laston lapis aus adalah sebagai lapisan aus, landasan, dan penahan beban. Berdasarkan ketentuan Divisi VI Perkerasan Aspal Departemen Pekerjaan Umum edisi Tahun 2010 Revisi 3 menyatakan bahwa tebal nominal minimum untuk lapisan aus adalah $4,0 \mathrm{~cm}$;

2. Laston lapis pengikat atau dikenal dengan nama Asphalt Concrete-Binder Course (AC-BC), merupakan lapisan yang terletak setelah lapisan AC-WC. Lapisan ini bekerja sebagai penerus beban yang diterimanya menuju fondasi. Oleh karena itu, kestabilan bahan penyusun lapisan ini sangat penting dalam menentukan kualitasnya, terutama dalam mengurangi regangan dan tegangan yang ditimbulkan oleh beban lalu lintas. Berdasarkan ketentuan Divisi VI Perkerasan Aspal Departemen Pekerjaan Umum edisi Tahun 2010 Revisi 3, tebal nominal minimum untuk lapisan pengikat adalah $6,0 \mathrm{~cm}$;

3. Laston lapis fondasi atau dikenal dengan nama Asphalt Concrete-Base (AC-Base), merupakan lapisan yang terletak paling bawah. Lapisan ini berperan penting dalam 
memberikan dukungan pada lapisan permukaan, mengurangi nominal tegangan dan regangan, serta meneruskan beban ke lapisan sub-grade yang berada di lapisan berikutnya. Berdasarkan ketentuan Divisi VI Perkerasan Aspal Departemen Pekerjaan Umum edisi Tahun 2010 Revisi 3, tebal nominal minimum untuk lapisan fondasi adalah $7,5 \mathrm{~cm}$.

Campuran laston merupakan hasil pencampuran antara agregat, aspal, bahan pengisi, dan atau bahan aditif. Sifat campuran yang harus dimiliki adalah sesuai dengan jenis laston yang dipilih. Ketentuan sifat campuran laston dapat dilihat pada Tabel 2.1.

Tabel 2.1 Ketentuan Sifat-sifat Campuran Laston (AC)

\begin{tabular}{|c|c|c|c|c|}
\hline \multirow{2}{*}{\multicolumn{2}{|c|}{ Sifat-sifat Campuran }} & \multicolumn{3}{|l|}{ Laston } \\
\hline & & \multirow{2}{*}{$\begin{array}{l}\text { Lapis Aus } \\
75\end{array}$} & \multirow[t]{2}{*}{$\begin{array}{l}\text { Lapis } \\
\text { Pengikat }\end{array}$} & \multirow{2}{*}{$\begin{array}{l}\begin{array}{l}\text { Lapis } \\
\text { Fondasi }\end{array} \\
112^{(1)} \\
\end{array}$} \\
\hline Jumlah Tumbukan per bidang & & & & \\
\hline \multirow{2}{*}{$\begin{array}{l}\text { Rasio partikel lolos ayakan } \\
0,075 \mathrm{~mm} \text { dengan kadar aspal } \\
\text { efektif }\end{array}$} & Min. & \multicolumn{3}{|l|}{1,0} \\
\hline & Max. & \multicolumn{3}{|l|}{1,4} \\
\hline \multirow{2}{*}{ Rongga dalam campuran $(\%)^{(2)}$} & Min. & \multicolumn{3}{|l|}{3,0} \\
\hline & Max. & \multicolumn{3}{|l|}{5,0} \\
\hline $\begin{array}{l}\text { Rongga dalam Agregat (VMA) } \\
(\%)\end{array}$ & Min. & 15 & 14 & 13 \\
\hline Rongga Terisi Aspal (\%) & Min. & 65 & 65 & 65 \\
\hline Stabilitas Marshall (kg) & Min. & \multicolumn{2}{|l|}{800} & $1800^{(1)}$ \\
\hline \multirow{2}{*}{ Pelelehan $(\mathrm{mm})$} & Min. & \multicolumn{2}{|l|}{2} & 3 \\
\hline & Max & \multicolumn{2}{|l|}{4} & $6^{(1)}$ \\
\hline $\begin{array}{l}\text { Stabilitas Marshall Sisa }(\%) \\
\text { setelah perendaman selama } 24 \\
\text { jam, } 60^{\circ} \mathrm{C}^{(3)}\end{array}$ & Min. & \multicolumn{3}{|l|}{90} \\
\hline $\begin{array}{l}\text { Rongga dalam campuran }(\%) \\
\text { pada Kepadatan membal } \\
{\text { (refusal) })^{(4)}}\end{array}$ & Min. & \multicolumn{3}{|l|}{2} \\
\hline
\end{tabular}

Keterangan:

1. Modifikasi Marshall lihat Lampiran 6.3.B.

2. Rongga dalam campuran dihitung berdasarkan pengujian Berat Jenis Maksimum Agregat $\left(\mathrm{G}_{\mathrm{mm}}\right.$ test, SNI 03-6893-2002).

3. Direksi Pekerjaan dapat atau menyetujui AASTHO T283-89 sebagai alternatif pengujian kepekaan terhadap kadar air. Pengkondisian beku cair (freezing thaw conditioning) tidak diperlukan.

4. Untuk menentukan kepadatan membal (refusal), disarankan menggunakan penumbuk bergetar (vibratory hammer) agar pecahnya butiran agregat dalam campuran dapat dihindari. Jika digunakan penumbuk manual jumlah tumbukan per bidang harus 600 untuk cetakan berdiameter 6 inci dan 400 untuk cetakan berdiameter 4 inci.

Sumber: Departemen Pekerjaan Umum, 2010 


\subsection{Genteng Keramik}

Penggunaan genteng pertama kali ditemukan di China, selama Zaman Neolitikum sekitar 10.000 SM, dan Timur Tengah beberapa waktu kemudian. Dari wilayah ini, penggunaan genteng tersebar ke seluruh Asia dan Eropa. Banyak faktor yang menyebabkan genteng digunakan secara luas sejak dahulu, salah satu faktornya adalah genteng tahan terhadap panas atau api.

Saat ini, genteng memiliki beragam jenis, seperti genteng terakota, genteng keramik, genteng beton, genteng metal, genteng fiber, dan genteng asbes. Genteng terakota adalah genteng yang terbuat dari tanah liat dan prosesnya dilakukan secara tradisional sehingga genteng ini memiliki keunggulan berupa harga lebih ekonomis dan bobot ringan. Genteng keramik terbuat dari keramik yang berbahan dasar tanah liat melalui proses fabrikasi sehingga pada lapisan teratasnya lebih licin dan mengkilap (finishing menggunakan glazur).

Genteng beton terbuat dari campuran agregat, semen, dan air. Genteng ini umumnya berbentuk datar (flat) dan memiliki bidang yang luas, sehingga saat ini genteng beton banyak digunakan. Genteng metal adalah genteng yang terbuat dari baja lapis ringan (zincalume steel) yang merupakan perpaduan seng, alumunium, dan silikon yang berbentuk lembaran bergelombang. Genteng fiber terbuat dari campuran semen, bahan penguat, dan serat mineral fiber sehingga menghasilkan bahan sekeras beton dan memiliki bentuk yang bergelombang. Genteng asbes merupakan perpaduan dari bahan mineral berupa serat yang menyerap panas dan sedikit merefleksikan sinar matahari.

Genteng keramik pada proses pembuatannya diawali dengan pembuatan badan genteng (body) yang menggunakan bahan baku berupa campuran beberapa jenis tanah liat. Sebelum diproses, tanah liat yang digunakan akan melalui beberapa pemeriksaan laboratorium untuk mengetahui struktur kandungannya. Parameter pemeriksaan mencakup pemeriksaan visual, tingkat plastisitas, kehalusan partikel, susut kering dan susut bakar, tingkat hilang pijar dan tingkat kontaminasi kapur. Badan genteng yang telah melalui proses formulasi tersebut masuk ke dalam proses penggilingan dengan tujuan untuk menyeragamkan dimensi partikel dan homogenisasi. Proses pembuatan badan genteng ini menggunakan beberapa mesin-mesin utama, seperti box feeder, roll crusher, pug mill, dan screen feeder. Seluruh rangkaian mesin ini disatukan dengan rangkaian conveyor yang berfungsi untuk mengantarkan material dari satu mesin ke mesin lainnya. Gambar 2.2 menunjukkan genteng keramik. 


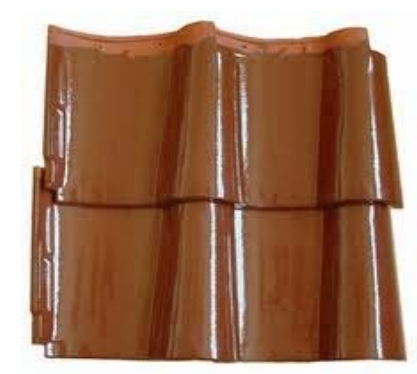

\section{Gambar 2.2 Genteng Keramik}

\subsection{Abu Terbang}

Abu terbang atau lebih dikenal dengan sebutan fly ash merupakan sisa hasil pembakaran batu bara pada pembangkit listrik. Abu terbang memiliki titik lebur sekitar $1300^{\circ} \mathrm{C}$ dan mempunyai kerapatan massa (densitas) antara $2,0-2,5 \mathrm{~g} / \mathrm{cm}^{3}$. Dalam kegiatan industri, abu terbang biasanya terbentuk oleh pengendap elektrostatik atau peralatan filtrasi partikel lain sebelum gas buang mencapai cerobong asap batu bara pembangkit listrik, dan bersama-sama dengan bottom ash dikeluarkan dari bagian bawah tungku. Tergantung pada jenis batu bara yang dibakar, abu terbang yang dihasilkan pun beragam, namun seluruh abu terbang memiliki kadar silikon dioksida $\left(\mathrm{SiO}_{2}\right)$ dan kalsium oksida $(\mathrm{CaO})$ yang besar.

Abu terbang memiliki dua tipe, yaitu: abu terbang tipe-C dan abu terbang tipe-F. Abu terbang tipe- $\mathrm{C}$ merupakan abu terbang dengan kadar $\mathrm{CaO}$ lebih dari $10 \%$ yang berasal dari pembakaran lignit atau batu bara muda. Dalam campuran beton, abu terbang tipe-C yang digunakan sebanyak $15 \%-35 \%$ dari berat silinder. Abu terbang tipe-F merupakan abu terbang dengan kadar $\mathrm{CaO}$ kurang dari $10 \%$ yang dihasilkan dari pembakaran antrasit atau bituminous batu bara. Dalam campuran beton, abu terbang tipeF yang digunakan sebanyak $15 \%-25 \%$ dari berat silinder.

Pada Tahun 1989, total abu terbang yang dihasilkan dari pembakaran batu bara di seluruh dunia mencapai 440 miliar ton. Sekitar 75\% adalah abu terbang. Penghasil utama adalah negara-negara bekas Uni Soviet (99 miliar ton), Tiongkok (55 miliar ton), Amerika Serikat (53 miliar ton), dan India (40 miliar ton). Tingkat penggunaan abu terbang dalam produksi semen saat ini masih tergolong rendah, faktanya hanya $15 \%$ dari produksinya digunakan Tiongkok sebagai bahan pembuatan beton.

Berbagai penelitian mengenai pengembangan abu terbang baru bara kian giat dilakukan untuk meningkatkan nilai ekonomisnya serta mengurangi dampak buruk terhadap lingkungan. Saat ini pada umumnya abu terbang digunakan dalam pabrik semen sebagai salah satu bahan campuran pembuat beton. Selain sebagai bahan campuran 
pembuat beton, abu terbang batu bara memiliki kegunaan beragam, seperti sebagai bahan penggosok (polisher), pengisi aspal, plastik dan kertas, serta sebagai aditif dalam pengolahan limbah (waste stabilization). Gambar 2.3 menunjukkan abu terbang.

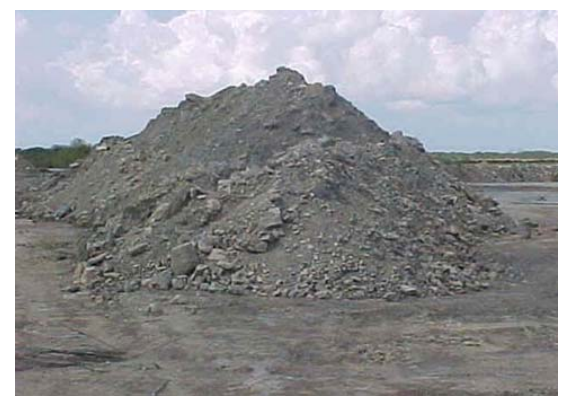

Gambar 2.3 Abu Terbang

\section{METODE PENELITIAN}

Pengujian aspal, agregat, bahan pengganti, dan bahan pengisi dilakukan di laboratorium Material Jalan Universitas Kristen Maranatha. Material yang digunakan pada penelitian ini yaitu kerikil dan pasir dari Lagadar, abu terbang tipe F dari PLTU Cibinong, genteng keramik berkekuatan tekan $180 \mathrm{kgf}$, dan bahan aspal menggunakan aspal penetrasi 60. Langkah awal sebelum dilakukan perancangan campuran adalah memilih fraksi agregat yang akan dicampur. Fraksi agregat yang digunakan dalam penelitian ini yaitu Asphalt Concrete-Binder Course (AC-BC).

Sebelum melakukan pencampuran pembuatan benda uji, hal pertama yang dilakukan adalah menghitung kadar aspal yang menjadi acuan untuk membuat benda uji Marshall agar diperoleh kadar aspal optimum. Nilai kadar aspal rencana yang didapat dibulatkan mendekati 0,5\%. Kemudian ditentukan kadar aspal rencana masing-masing 2 ke atas dan 2 ke bawah. Langkah-langkah pembuatan benda uji adalah:

\section{A. Mencari Kadar Aspal Optimum}

1. Berdasarkan perkiraan kadar aspal rencana, yaitu $\mathrm{Pb}-1 \% ; \mathrm{Pb}-0,5 \%, \mathrm{~Pb} \% ; \mathrm{Pb}+0,5 \%$; dan $\mathrm{Pb}+1 \%$ maka dibuat 3 benda uji untuk masing-masing kadar aspal. Total benda uji untuk mendapatkan kadar aspal optimum adalah 15 benda uji dari kadar bahan pengisi $100 \%$ abu terbang.

2. Setiap benda uji diperlukan agregat sebanyak \pm 1200 gr dengan diameter 4inci. Panaskan wadah pencampur beserta agregat kira-kira $28^{\circ} \mathrm{C}$ di atas temperatur pencampuran. Sementara itu, panaskan juga aspal sampai temperatur pencampuran.

3. Kemudian tuangkan aspal sebanyak yang dibutuhkan ke dalam wadah yang sudah dipanaskan tersebut. Aduklah dengan cepat sampai agregat terlapis sementara. 
4. Dilakukan tes kompaksi uji Marshall standar dengan $2 \times 75$ tumbukan untuk semua benda uji.

5. Benda uji yang telah dikompaksi akan didiamkan hingga mengeras selama $\pm 24 \mathrm{jam}$.

6. Kemudian lakukan tes marshall untuk mendapatkan kadar aspal optimum dan parameter Marshall, yaitu VIM, VMA, VFA, stabilitas, pelelehan, dan lainnya sesuai dengan spesifikasi campuran.

B. Mendapatkan Kadar Aspal Optimum

Kadar aspal optimum yang diperoleh kemudian digunakan untuk mendapatkan hasil perbandingan antara penggunaan $0 \%$ genteng keramik; $25 \%$ genteng keramik dan $75 \%$ kerikil; $50 \%$ genteng keramik dan 50\% kerikil; $75 \%$ genteng keramik dan $25 \%$ kerikil; $100 \%$ genteng keramik.

\section{ANALISIS DATA}

Proporsi agregat campuran didapatkan dengan melakukan analisis ayakan berdasarkan agregat yang digunakan. Agregat yang digunakan adalah agregat kasar, agregat halus, dan bahan pengisi. Gradasi agregat gabungan untuk campuran aspal dapat dilihat pada Tabel 2.2

Tabel 2.2 Gradasi Agregat Gabungan untuk Campuran Aspal

\begin{tabular}{|l|l|l|l|}
\hline \multirow{3}{*}{$\begin{array}{l}\text { Ukuran } \\
(\mathbf{m m})\end{array}$} & $\begin{array}{l}\text { \% Berat Yang Lolos terhadap Total Agregat dalam } \\
\text { Campuran }\end{array}$ & \multicolumn{2}{l|}{} \\
\cline { 2 - 4 } & Laston (AC) & BC & Base \\
\cline { 2 - 4 } & WC & & 100 \\
\hline 37,5 & & 100 & $90-100$ \\
\hline 25 & & $90-100$ & $76-90$ \\
\hline 19 & 100 & $75-90$ & $60-78$ \\
\hline 12,5 & $90-100$ & $66-82$ & $52-71$ \\
\hline 9,5 & $77-90$ & $46-64$ & $35-54$ \\
\hline 4,75 & $53-69$ & $30-49$ & $23-41$ \\
\hline 2,36 & $33-53$ & $18-38$ & $13-30$ \\
\hline 1,18 & $21-40$ & $12-28$ & $10-22$ \\
\hline 0,6 & $14-30$ & $7-20$ & $6-15$ \\
\hline 0,3 & $9-22$ & $5-13$ & $4-10$ \\
\hline 0,15 & $6-15$ & $4-8$ & $3-7$ \\
\hline 0,075 & $4-9$ & & \\
\hline
\end{tabular}

Sumber: Departemen Pekerjaan Umum, 2010

Pengujian aspal dilakukan untuk mengetahui sifat fisik dan kimiawi aspal. Pengujian berat jenis untuk mengukur berat jenis aspal dengan menggunakan piknometer dengan perbandingan berat di udara dan berat di dalam air. Pengujian kekerasan aspal 
yang dilakukan dengan pengujian penetrasi, yaitu dengan menggunakan jarum penetrasi berdiameter $1 \mathrm{~mm}$ dan beban 50gr. Pengujian daktilitas untuk mengetahui sifat kohesi dan plastisitas aspal. Nilai daktilitas aspal adalah panjang contoh aspal ketika putus pada saat dilakukannya penarikan dengan kecepatan $5 \mathrm{~cm} /$ menit. Pengujian titik nyala dan titik bakar untuk memperkirakan temperatur maksimum pemanasan aspal sehingga aspal tidak terbakar. Temperatur yang didapat adalah simulasi terhadap temperatur maksimum yang biasa terjadi pada aspal sampai aspal mengalami kerusakan permanen. Pengujian titik lembek untuk mengetahui temperatur aspal mulai lembek, pengujian ini dilakukan menggunakan alat ring and ball. Temperatur yang didapat menjadi acuan di lapangan atas kemampuan aspal menahan temperatur permukaan yang terjadi untuk tidak lembek sehingga dapat mengurangi daya lekatnya. Tabel 2.3 menunjukkan pengujian kualitas aspal.

Tabel 2.3 Pengujian Kualitas Aspal

\begin{tabular}{|l|l|l|l|l|l|}
\hline No. & Jenis Pengujian & Standar Pengujian & Hasil & $\begin{array}{l}\text { Spesifikasi } \\
\text { Binamarga, } \\
\mathbf{2 0 1 0} \text { Rev.3 }\end{array}$ & Keterangan \\
\hline 1. & Berat Jenis & SNI 2441:2011 & 1,02 & $\geq 1,0$ & Memenuhi \\
\hline 2. & Penetrasi & SNI 06-2456-1991 & 61 & $60-70$ & Memenuhi \\
\hline 3. & Titik Lembek $\left({ }^{\circ} \mathrm{C}\right)$ & SNI $2434: 2011$ & 52 & $\geq 48$ & Memenuhi \\
\hline 4. & Titik Nyala $\left({ }^{\circ} \mathrm{C}\right)$ & SNI $2433: 2011$ & 335 & $\geq 232$ & Memenuhi \\
\hline 5. & Daktilitas $(\mathrm{cm})$ & SNI $2432: 2011$ & 150 & $\geq 100$ & Memenuhi \\
\hline
\end{tabular}

Pengujian agregat kasar bertujuan untuk mengetahui sifat fisik dan kimiawi agregat. Pengujian berat jenis agregat dilakukan untuk mengekspresikan nilai kerapatan/density agregat, dimana nilai kerapatan agregat diperoleh dengan mengalikan nilai berat jenis agregat dengan kerapatan air pada temperatur standar yang dipakai untuk pengukuran. Pengujian abrasi dengan menggunakan mesin Los Angeles diperlukan untuk mengetahui ketahanan agregat kasar terhadap keausan. Keausan tersebut dinyatakan dengan perbandingan antara berat bahan aus lewat ayakan No. 12 terhadap berat semula dalam persen (\%). Daya lekat aspal terhadap agregat dipengaruhi oleh sifat agregat terhadap air.

Agregat yang mudah menyerap air akan sulit untuk mengikat aspal, sehingga ikatan aspal dan agregat mudah lepas. Sebaliknya agregat yang sulit menyerap air akan mudah mengikat aspal, sehingga ikatan aspal dan agregat tidak mudah lepas. Pengujian partikel pipih dan lonjong dilakukan untuk mengetahui banyaknya agregat yang berbentuk lonjong dan pipih. Agregat dikatakan lonjong jika ukuran terpanjangnya lebih dari 1,8 kali diameter rata-rata. Indeks kelonjongan (elongated index) adalah persentase 
berat agregat lonjong terhadap berat total, sedangkan agregat pipih, yaitu agregat yang ketebalannya lebih tipis dari 0,6 kali diameter rata-rata. Pengujian material lolos ayakan No.200 dilakukan untuk mendapatkan jumlah kadar lumpur yang terdapat pada agregat kasar. Hasil perhitungan pengujian agregat kasar dapat dilihat pada Tabel 2.4.

Tabel 2.4 Pengujian Agregat Kasar

\begin{tabular}{|c|c|c|c|c|c|}
\hline \multicolumn{6}{|c|}{ Agregat kasar: Kerikil } \\
\hline No. & Pengujian & $\begin{array}{l}\text { Standar } \\
\text { Pengujian }\end{array}$ & Hasil & \begin{tabular}{lc}
\multicolumn{2}{l}{ Spesifikasi } \\
Div.6 & Bina \\
Marga & 2010, \\
Rev.3 & \\
\end{tabular} & Keterangan \\
\hline 1. & Berat Jenis Bulk & $\begin{array}{l}\text { SNI 03-1969- } \\
1990\end{array}$ & 2,491 & - & - \\
\hline 2. & Berat Jenis SSD & $\begin{array}{l}\text { SNI 03-1969- } \\
1990\end{array}$ & 2,560 & - & - \\
\hline 3. & $\begin{array}{|ll|}\text { Berat } & \text { Jenis } \\
\text { Apparent } & \\
\end{array}$ & $\begin{array}{l}\text { SNI 03-1969- } \\
1990\end{array}$ & 2,675 & - & - \\
\hline 4. & Berat Isi & $\begin{array}{l}\text { SNI 03-1969- } \\
1990\end{array}$ & $\begin{array}{l}1,19 \\
\mathrm{~T} / \mathrm{m}^{3}\end{array}$ & & \\
\hline 5. & Penyerapan Air & $\begin{array}{l}\text { SNI 03-1969- } \\
1990\end{array}$ & 2,752 & - & - \\
\hline 6. & $\begin{array}{|lr|}\text { Abrasi } & \text { dengan } \\
\text { Mesin } & \text { Los } \\
\text { Angeles } & \\
\end{array}$ & $\begin{array}{l}\text { SNI } \\
2417: 2008\end{array}$ & $18,47 \%$ & Maks. $40 \%$ & Memenuhi \\
\hline 7. & \begin{tabular}{|l|} 
Kelekatan \\
agregat terhadap \\
aspal
\end{tabular} & $\begin{array}{l}\text { SNI } \\
2439: 2011\end{array}$ & $98 \%$ & Min. 95\% & Memenuhi \\
\hline 8. & 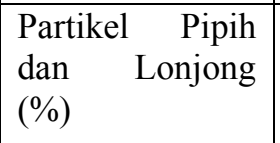 & $\begin{array}{l}\text { ASTM D4791 } \\
\text { Perbandingan } \\
1: 5\end{array}$ & $7,21 \%$ & Maks. $10 \%$ & Memenuhi \\
\hline 9. & \begin{tabular}{|l|} 
Material Lolos \\
Ayakan No.200 \\
\end{tabular} & $\begin{array}{l}\text { SNI 03-4142- } \\
1996\end{array}$ & $0 \%$ & Maks. 2\% & Memenuhi \\
\hline \multicolumn{6}{|c|}{ Agregat kasar : Genteng Keramik } \\
\hline $\begin{array}{l}\text { No } \\
\cdot\end{array}$ & Pengujian & $\begin{array}{l}\text { Standar } \\
\text { Pengujian }\end{array}$ & Hasil & $\begin{array}{l}\text { Spesifikasi } \\
\text { Div.6 Bina } \\
\text { Marga } \\
\text { 2010, Rev.3 }\end{array}$ & Keterangan \\
\hline 1. & Berat Jenis Bulk & $\begin{array}{l}\text { SNI 03-1969- } \\
1990\end{array}$ & 1,977 & - & - \\
\hline 2. & Berat Jenis SSD & $\begin{array}{l}\text { SNI 03-1969- } \\
1990\end{array}$ & 2,171 & - & - \\
\hline 3. & $\begin{array}{l}\text { Berat Jenis } \\
\text { Apparent }\end{array}$ & $\begin{array}{l}\text { SNI 03-1969- } \\
1990\end{array}$ & 2,454 & - & - \\
\hline 4. & Berat Isi & $\begin{array}{l}\text { SNI 03-1969- } \\
1990\end{array}$ & $\begin{array}{l}1,05 \\
\mathrm{~T} / \mathrm{m}^{3}\end{array}$ & & \\
\hline
\end{tabular}




\begin{tabular}{|c|c|c|c|c|c|}
\hline 5. & Penyerapan Air & $\begin{array}{l}\text { SNI 03-1969- } \\
1990\end{array}$ & 9,84 & - & - \\
\hline 6. & $\begin{array}{lr}\text { Abrasi } & \text { dengan } \\
\text { Mesin } & \text { Los } \\
\text { Angeles } & \end{array}$ & $\begin{array}{l}\text { SNI } \\
2417: 2008\end{array}$ & $39,87 \%$ & Maks. $40 \%$ & Memenuhi \\
\hline 7. & $\begin{array}{l}\text { Kelekatan agregat } \\
\text { terhadap aspal }\end{array}$ & \begin{tabular}{|l} 
SNI \\
$2439: 2011$ \\
\end{tabular} & $98 \%$ & Min. 95\% & Memenuhi \\
\hline 8. & $\begin{array}{l}\text { Partikel Pipih dan } \\
\text { Lonjong }\end{array}$ & $\begin{array}{l}\text { ASTM D4791 } \\
\text { Perbandingan } \\
1: 5\end{array}$ & $9,81 \%$ & Maks. $10 \%$ & Memenuhi \\
\hline 9. & $\begin{array}{l}\text { Material Lolos } \\
\text { Ayakan No. } 200\end{array}$ & $\begin{array}{l}\text { SNI 03-4142- } \\
1996\end{array}$ & $2 \%$ & Maks. $2 \%$ & Memenuhi \\
\hline
\end{tabular}

Pengujian agregat halus bertujuan untuk mengetahui sifat fisik dan kimiawi agregat halus. Standar pengujian dan hasil pengujian agregat halus dapat dilihat pada Tabel 2.5.

Tabel 2.5 Pengujian Agregat Halus

\begin{tabular}{|l|l|l|l|l|l|}
\hline No. & Pengujian & $\begin{array}{l}\text { Standar } \\
\text { Pengujian }\end{array}$ & Hasil & $\begin{array}{l}\text { Spesifikasi Div.6 } \\
\text { Bina Marga, 2010 } \\
\text { Rev.3 }\end{array}$ & Keterangan \\
\hline 1. & Nilai Setara Pasir & $\begin{array}{l}\text { SNI 03- } \\
4428-1997\end{array}$ & $75 \%$ & Min. 60\% & Memenuhi \\
\hline 2. & $\begin{array}{l}\text { Angularitas } \\
\text { dengan Uji Kadar } \\
\text { Rongga }\end{array}$ & $\begin{array}{l}\text { SNI 03- } \\
6877-2002\end{array}$ & 92,56 & Min. 45 & Memenuhi \\
\hline 3. & $\begin{array}{l}\text { Agregat Lolos } \\
\text { Ayakan No.200 }\end{array}$ & $\begin{array}{l}\text { SNI ASTM } \\
\text { C117:2012 }\end{array}$ & 3,90 & Maks. 10\% & Memenuhi \\
\hline 4. & Berat Jenis Bulk & $\begin{array}{l}\text { SNI 03- } \\
1970-1990\end{array}$ & 2,32 & - & - \\
\hline 5. & Berat Jenis SSD & $\begin{array}{l}\text { SNI 03- } \\
1970-1990\end{array}$ & 2,45 & - & - \\
\hline 6. & $\begin{array}{l}\text { Berat Jenis } \\
\text { Apparent }\end{array}$ & $\begin{array}{l}\text { SNI 03- } \\
1970-1990\end{array}$ & 2,66 & - & - \\
\hline 7. & Berat Isi & $\begin{array}{l}\text { SNI 03- } \\
1969-1990\end{array}$ & 1,45 \\
T/m $\mathrm{m}^{3}$ & & - \\
\hline 7. & Penyerapan Air & $\begin{array}{l}\text { SNI 03- } \\
1970-1990\end{array}$ & 5,57 & - & \\
\hline
\end{tabular}

Pengujian bahan pengisi bertujuan untuk membatasi bahwa bahan pengisi yang dapat ditambahkan adalah bahan pengisi yang kering dan bebas dari gumpalan-gumpalan dan bila diuji dengan pengayakan sesuai SNI ASTM C136: 2012 harus mengandung bahan yang lolos ayakan No. 200 tidak kurang dari 75\% terhadap beratnya sendiri kecuali untuk mineral asbuton. Pengujian bahan pengisi dapat dilihat pada Tabel 2.6. 
Tabel 2.6 Pengujian Bahan Pengisi

\begin{tabular}{|l|l|l|l|l|l|}
\hline No. & Pengujian & $\begin{array}{l}\text { Standar } \\
\text { Pengujian }\end{array}$ & Hasil & $\begin{array}{l}\text { Spesifikasi Div.6 } \\
\text { Bina Marga, } \\
\mathbf{2 0 1 0} \text { Rev.3 }\end{array}$ & Keterangan \\
\hline 1. & Berat Jenis & $\begin{array}{l}\text { AASTHO T- } \\
85-81\end{array}$ & 2,56 & - & - \\
\hline 2. & Berat Isi & $\begin{array}{l}\text { AASTHO T- } \\
85-81\end{array}$ & $\begin{array}{l}1,69 \\
\text { T/m }\end{array}$ & - & - \\
\hline
\end{tabular}

Fraksi agregat kasar, agregat halus, dan bahan pengisi digunakan untuk menentukan kadar aspal rencana. Kadar aspal rencana tersebut digunakan untuk mencari kadar aspal optimum. Ketiga jenis fraksi agregat tersebut berasal dari penentuan proporsi agregat campuran. Kadar aspal rencana yang telah diperoleh dapat dilihat pada Tabel 2.7.

Tabel 2.7 Kadar Aspal Rencana

\begin{tabular}{|c|c|c|c|c|}
\hline \multicolumn{5}{|c|}{ Kadar Aspal Rencana } \\
\hline \multicolumn{2}{|c|}{ Batas Bawah } & $\mathrm{Pb}$ & \multicolumn{2}{c|}{ Batas Atas } \\
\hline$-1,0 \%$ & $-0,5 \%$ & $\mathrm{~Pb}$ & $+0,5 \%$ & $+1,0 \%$ \\
\hline $6,0 \%$ & $6,5 \%$ & $7,0 \%$ & $7,5 \%$ & $8,0 \%$ \\
\hline
\end{tabular}

Rata-rata hasil pengujian Marshall pada kadar aspal rencana dapat dilihat pada Tabel 2.8.

Tabel 2.8 Rata-rata Hasil Pengujian Marshall pada Kadar Aspal Rencana

\begin{tabular}{|l|l|l|l|l|l|}
\hline Parameter & \multicolumn{5}{|l|}{ Kadar Aspal (\%) } \\
\cline { 2 - 6 } Marshall & 6 & 6,5 & 7 & 7,5 & 8 \\
\hline $\begin{array}{l}\text { VIM } \\
(\%)\end{array}$ & 6,72 & 5,89 & 4,29 & 4,03 & 3,77 \\
\hline $\begin{array}{l}\text { VMA } \\
(\%)\end{array}$ & 17,81 & 18,13 & 17,77 & 18,57 & 19,38 \\
\hline $\begin{array}{l}\text { VFA } \\
(\%)\end{array}$ & 62,32 & 67,49 & 75,87 & 78,33 & 80,53 \\
\hline $\begin{array}{l}\text { Stabilitas } \\
\text { (kg) }\end{array}$ & 799,61 & 830,58 & 771,28 & 733,89 & 710,83 \\
\hline $\begin{array}{l}\text { Flow } \\
(\mathrm{mm})\end{array}$ & 6,42 & 6,67 & 7,09 & 7,45 & 7,77 \\
\hline $\begin{array}{l}\text { MQ } \\
(\mathrm{kg} / \mathrm{mm})\end{array}$ & 124,62 & 124,46 & 108,79 & 98,47 & 91,49 \\
\hline
\end{tabular}

Hubungan kadar aspal dengan VMA dapat dilihat pada Gambar 2.4. Pada Gambar 2.4 dapat disimpulkan bahwa untuk kadar aspal 6\% sampai dengan $8 \%$ lolos persyaratan yang digunakan. Kadar aspal dengan VIM dapat dilihat pada Gambar 2.5. 


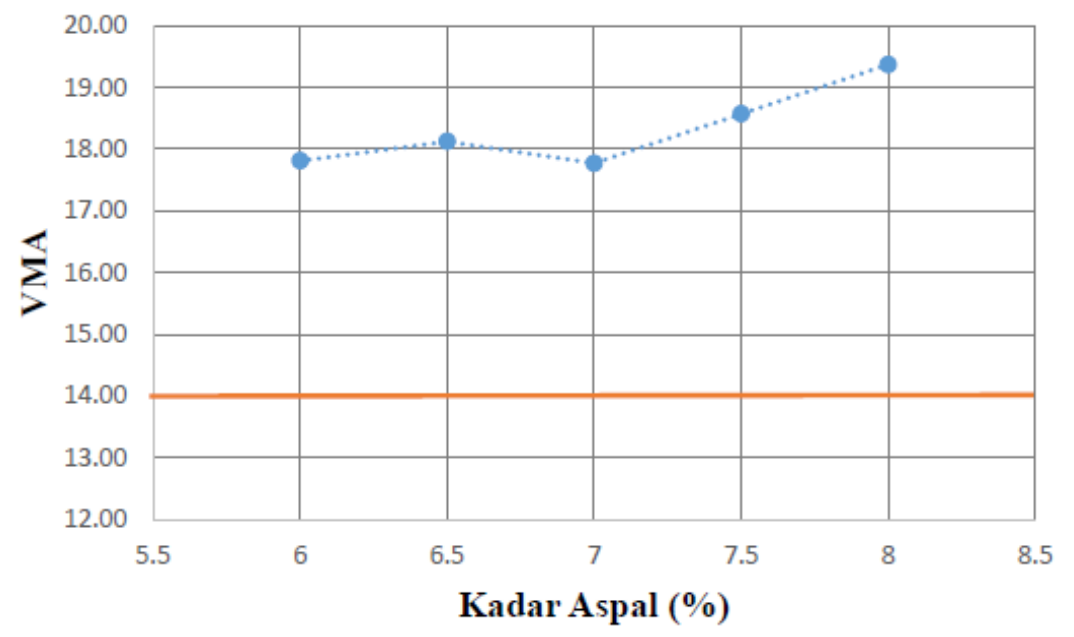

Gambar 2.4 Hubungan Kadar Aspal dengan VMA

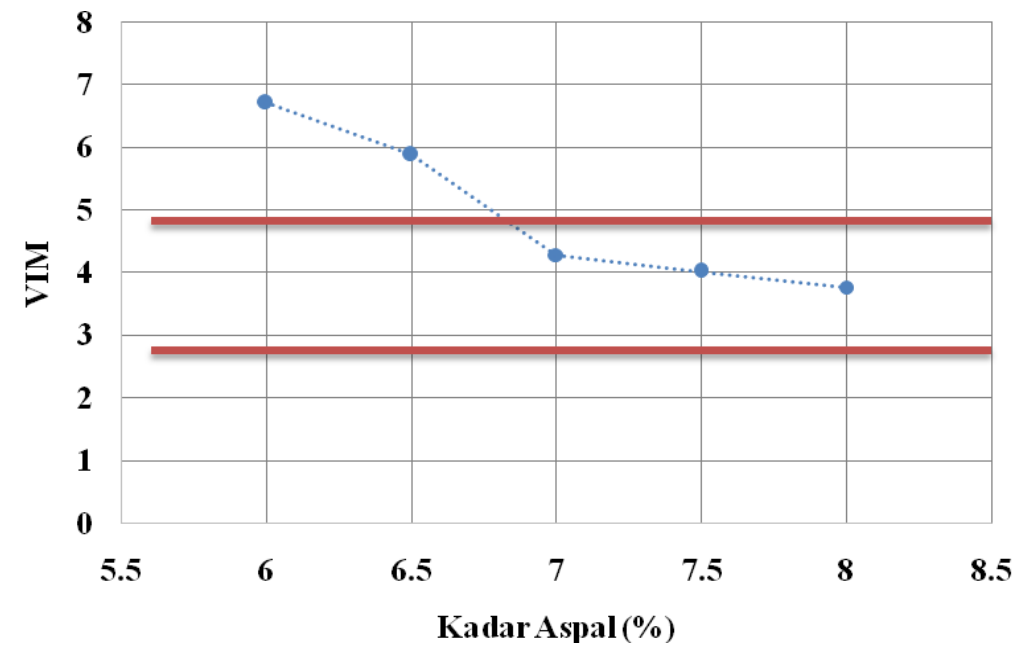

Gambar 2.5 Hubungan Kadar Aspal dengan VIM

Pada Gambar 2.5 dapat disimpulkan bahwa nilai VIM pada kadar aspal 6\% hingga $6,5 \%$ ke $7 \%$ berada pada batas maksimum persyaratan yang digunakan. Selain itu, pada kadar aspal $6,5 \%$ ke $7 \%$ hingga kadar aspal $8 \%$ memiliki nilai VIM yang sesuai dengan persyaratan yang digunakan.

Semakin kecil rongga udara maka campuran beraspal akan semakin kedap terhadap air, tetapi udara tidak dapat masuk ke dalam lapisan beraspal sehingga aspal menjadi rapuh dan getas. Semakin besar rongga udara dan kadar aspal yang rendah akan mengakibatkan pelelehan yang lebih cepat. Hubungan kadar aspal dengan pelelehan dapat dilihat pada Gambar 2.6. 


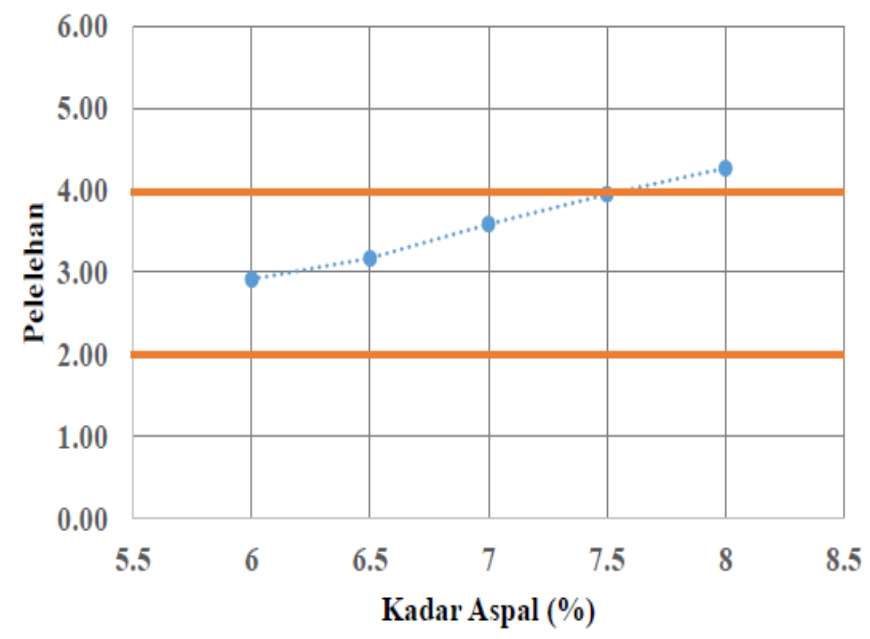

Gambar 2.6 Hubungan Kadar Aspal dengan Pelelehan

Pada Gambar 2.6 dapat disimpulkan bahwa pelelehan pada kadar aspal 7,5\% ke $8 \%$ berada di atas batas maksimum spesifikasi pada persyaratan yang digunakan, sedangkan kadar aspal 6\% hingga 7,5\% memenuhi spesifikasi pada persyaratan yang digunakan. Hubungan kadar aspal dengan stabilitas dapat dilihat pada Gambar 2.7.

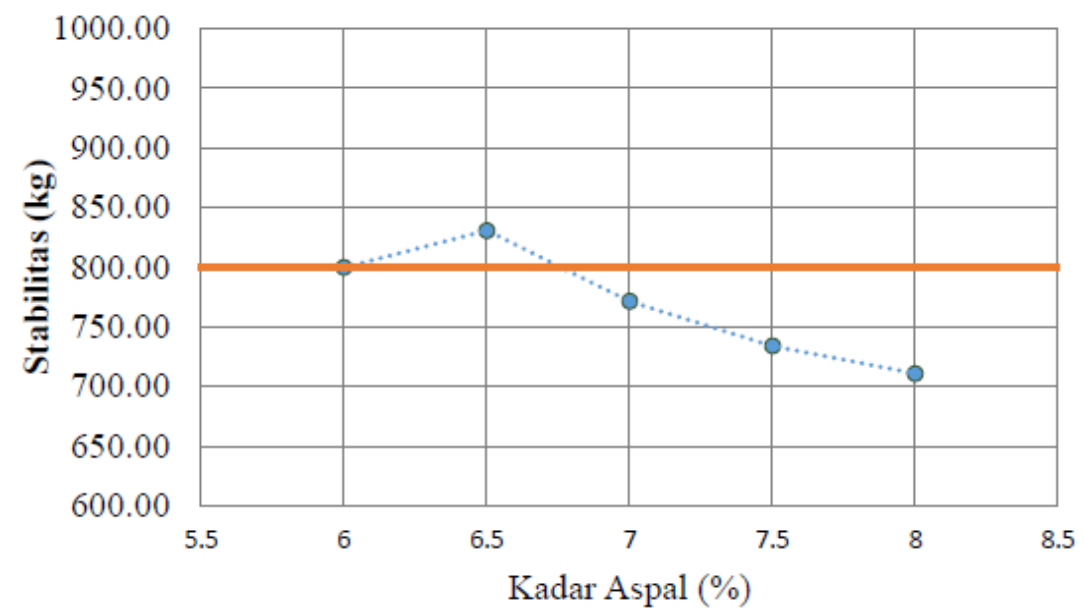

Gambar 2.7 Hubungan Kadar Aspal dengan Stabilitas

Pada Gambar 2.7 dapat disimpulkan bahwa nilai stabilitas tertinggi terdapat pada kadar aspal 6,5\% yaitu sebesar 830,58kg. Nilai stabilitas ditentukan berdasarkan material pada campuran beton aspal. Penentuan hasil kadar aspal optimum yang dicari melalui 
kadar aspal rencana dan melalui pembacaan grafik hasil pengujian Marshall dapat dilihat pada Gambar 2.8.

\begin{tabular}{|c|c|c|c|c|c|c|}
\hline \multirow{2}{*}{$\begin{array}{l}\text { Parameter } \\
\text { Marshall }\end{array}$} & \multicolumn{6}{|c|}{ Rentang Kadar Aspal yang memenuhi Spesifikasi } \\
\hline & 6 & 6,5 & 7 & 7,5 & 8 & \\
\hline \multicolumn{7}{|l|}{ Stabilitas } \\
\hline \multicolumn{7}{|l|}{\begin{tabular}{|l|} 
Pelelehan \\
\end{tabular}} \\
\hline \multicolumn{7}{|l|}{ VIM } \\
\hline VMA & & & & & & \\
\hline & & & & & & 6,75 \\
\hline
\end{tabular}

Gambar 2.8 Kadar Aspal Optimum

Kadar aspal optimum yang telah didapatkan kemudian digunakan untuk pengujian Marshall selanjutnya terhadap lima jenis campuran agregat kasar yang berbeda komposisi. Uji Marshall yang dilakukan menggunakan pengujian 2x75 tumbukan sesuai pada spesifikasi yang digunakan. Nomor benda uji dibagi berdasarkan komposisi campuran agregat kasar, nomor benda uji 1 mewakili komposisi campuran pada $100 \%$ kerikil, nomor benda uji 2 mewakili komposisi campuran pada $100 \%$ genteng keramik, nomor benda uji 3 mewakili komposisi campuran pada 25\% genteng keramik dan 75\% kerikil, nomor benda uji 4 mewakili komposisi campuran pada 50\% genteng keramik dan $50 \%$ kerikil, serta nomor benda uji 5 mewakili komposisi campuran pada 75\% genteng keramik dan 25\% kerikil. Rata-rata hasil pengujian Marshall dengan kadar aspal optimum dapat dilihat pada Tabel 2.9.

Tabel 2.9 Rata-rata Hasil Pengujian Marshall pada Kadar Aspal Optimum

\begin{tabular}{|c|c|c|c|c|c|c|c|}
\hline \multirow{3}{*}{$\begin{array}{l}\text { Parameter } \\
\text { Marshall }\end{array}$} & \multirow{2}{*}{\multicolumn{2}{|c|}{$\begin{array}{l}\text { Spesifikasi Div. } 6 \\
\text { Bina Marga, } 2010 \\
\text { Rev.3 }\end{array}$}} & \multicolumn{5}{|c|}{ Campuran Agregat Kasar } \\
\hline & & & \multirow{2}{*}{$100 \% \mathrm{~K}$} & \multirow{2}{*}{$\begin{array}{l}100 \% \\
\text { GK }\end{array}$} & \multirow{2}{*}{$\begin{array}{l}25 \% \mathrm{GK}: \\
75 \% \mathrm{~K}\end{array}$} & \multirow{2}{*}{$\begin{array}{l}50 \% \\
\text { GK: } \\
50 \% \mathrm{~K} \\
\end{array}$} & \multirow{2}{*}{$\begin{array}{l}75 \% \\
\text { GK: } \\
25 \% \mathrm{~K} \\
\end{array}$} \\
\hline & Min. & Maks. & & & & & \\
\hline $\begin{array}{l}\text { Stabilitas } \\
(\mathrm{kg})\end{array}$ & 800 & - & 928,61 & 496,88 & 779,96 & 820,95 & 714,81 \\
\hline VMA (\%) & 14 & - & 16,75 & 28,40 & 25,67 & 27,67 & 29,22 \\
\hline VIM (\%) & 3 & 5 & 3,70 & 17,18 & 14,03 & 16,34 & 18,13 \\
\hline $\begin{array}{l}\text { Pelelehan } \\
(\%)\end{array}$ & 2 & 4 & 3,34 & $\mathbf{3 , 4 7}$ & 3,33 & 4,06 & 3,89 \\
\hline \multicolumn{8}{|c|}{$\begin{array}{l}\text { Keterangan: } \\
\text { K : Kerikil } \\
\text { GK : Genteng }\end{array}$} \\
\hline
\end{tabular}


Pada Tabel 2.9 dapat disimpulkan pada campuran agregat kasar 100\% kerikil memenuhi seluruh persyaratan Stabilitas, VMA, VIM dan pelelehan. Pada campuran agregat kasar $100 \%$ genteng keramik hanya memenuhi persyaratan pada parameter VMA, dan tidak memenuhi persyaratan pada parameter stabilitas, VIM, dan pelelehan. Pada campuran agregat kasar $25 \%$ genteng keramik dan $75 \%$ kerikil memenuhi persyaratan pada parameter VMA dan pelelehan, serta tidak memenuhi persyaratan pada parameter stabilitas, dan VIM.

Pada campuran agregat kasar 50\% genteng keramik dan 50\% kerikil hanya memenuhi persyaratan pada parameter stabilitas, dan VMA, serta tidak memenuhi persyaratan pada parameter VIM, dan pelelehan. Pada campuran agregat kasar 75\% genteng keramik dan $25 \%$ kerikil hanya memenuhi persyaratan pada parameter VMA dan tidak memenuhi persyaratan pada parameter stabilitas, VIM, dan pelelehan. Dapat disimpulkan secara keseluruhan bahwa dari kelima jenis pengujian dengan campuran agregat kasar yang berbeda, laston lapis pengikat gradasi kasar lebih cocok menggunakan bahan agregat kasar berupa 100\% kerikil karena memiliki stabilitas dan parameter Marshall yang lolos spesifikasi.

\section{SIMPULAN DAN SARAN}

Berdasarkan hasil analisis data dengan kelima jenis campuran agregat kasar, yaitu: $100 \%$ kerikil, $100 \%$ genteng keramik, 25\% genteng keramik dan $75 \%$ kerikil, $50 \%$ genteng keramik dan 50\% kerikil, serta 75\% genteng keramik dan 25\% kerikil, dapat disimpulkan bahwa:

1. Kadar aspal optimum yang diperoleh sebesar $6,75 \%$.

2. Hasil analisis yang didapatkan dari tiap jenis campuran agregat kasar:

a. Nilai stabilitas yang tertinggi terdapat pada campuran agregat kasar 100\% kerikil, yaitu sebesar $928,61 \mathrm{~kg}$. Nilai stabilitas lainnya yang memenuhi spesifikasi adalah pada campuran $50 \%$ genteng keramik dan $50 \%$ kerikil, yaitu sebesar $820,95 \mathrm{~kg}$. Sementara itu nilai stabilitas pada campuran $25 \%$ genteng keramik dan $75 \%$ kerikil, $75 \%$ genteng keramik dan 25\% kerikil, serta 100\% genteng keramik tidak memenuhi batas minimum spesifikasi yaitu $800 \mathrm{~kg}$.

b. Nilai VMA pada seluruh jenis campuran agregat kasar memenuhi batas minimum spesifikasi sebesar 14\%. Nilai VMA terbesar secara berurutan, yaitu $75 \%$ genteng keramik dan 25\% kerikil, 100\% genteng keramik, 50\% genteng keramik dan 50\% kerikil, 25\% genteng keramik dan 75\% kerikil, serta 100\% kerikil dengan nilainya masing-masing sebesar $29,22 \%, 28,40 \%, 27,67 \%, 25,67 \%$, dan $16,75 \%$.

Penggunaan Genteng Keramik Sebagai Pengganti Agregat Kasar Dan Abu Terbang Sebagai Pengisi Pada Laston Ac-Bc (Kevin Doan Panjaitan, Tan Lie Ing) 
c. Nilai VIM pada campuran agregat kasar yang memenuhi spesifikasi hanya terdapat pada $100 \%$ kerikil dengan nilai sebesar 3,70\%. Hal ini disebabkan karena genteng keramik memiliki daya serap yang besar terhadap air sehingga sulit untuk menyerap aspal.

d. Pelelehan pada campuran agregat kasar yang memenuhi spesifikasi hanya terdapat pada $100 \%$ kerikil, dan $25 \%$ genteng keramik dan $75 \%$ kerikil dengan nilai sebesar $3,47 \%$ dan $3,33 \%$.

Berdasarkan hasil analisis yang telah dilakukan, penggunaan campuran dengan menggunakan genteng keramik tidak disarankan.

\section{DAFTAR PUSTAKA}

1. Adnan, 2003, Proses Pembuatan Genteng, Jurnal, Sekolah Tinggi Ilmu Kesehatan Binawan, Jakarta.

2. Aprilia, H., 2009, Evaluasi Pelaksanaan Program Transmigrasi Lokal Model Ring I Pola Tani di Bugel, Kec. Panjatan, Kab. Kulon Progo dan Gesing, Kec. Panggang Kab. Gunung Kidul, Tesis, MPKD Universitas Gadjah Mada, Yogyakarta.

3. Ardiansyah, 2010, "Fly Ash" Pemanfaatan dan Kegunaannya, https://ronymedia.wordpress.com/2010/05/26/fly-ash-pemanfaatankegunaannya/, 17 Januari 2017.

4. Badan Standardisasi Nasional, 1991, SNI 06-2433-1991, Cara Uji Titik Nyala dan Titik Bakar Aspal dengan Alat Cleveland Open Cup, Departemen Pekerjaan Umum, Badan Penelitian dan Pengembangan Departemen Pekerjaan Umum.

5. Badan Standardisasi Nasional, 1991, SNI 06-2434-1991, Cara Uji Titik Lembek Aspal dengan Alat Cincin dan Bola (Ring and Ball), Departemen Pekerjaan Umum, Badan Penelitian dan Pengembangan Departemen Pekerjaan Umum.

6. Badan Standardisasi Nasional, 1991, SNI 03-2439-1991, Cara Uji Kelekatan Agregat Terhadap Aspal, Departemen Pekerjaan Umum, Badan Penelitian dan Pengembangan Departemen Pekerjaan Umum.

7. Badan Standardisasi Nasional, 1991, SNI 06-2441-1991, Cara Uji Berat Jenis Aspal Keras, Departemen Pekerjaan Umum, Badan Penelitian dan Pengembangan Departemen Pekerjaan Umum.

8. Badan Standardisasi Nasional, 1991, SNI 06-2456-1991, Cara Uji Penetrasi Aspal, Departemen Pekerjaan Umum, Badan Penelitian dan Pengembangan Departemen Pekerjaan Umum. 
9. Badan Standardisasi Nasional, 2008, SNI 2417:2008, Cara Uji Keausan Agregat dengan Mesin Abrasi Los Angeles, Departemen Pekerjaan Umum, Badan Penelitian dan Pengembangan Departemen Pekerjaan Umum.

10. Departemen Permukiman dan Prasarana Wilayah, 2002, Pt T-01-2002-B, Pedoman Perencanaan Tebal Perkerasan Lentur.

11. Kementerian Pekerjaan Umum, 2010, Spesifikasi Umum Perkerasan Aspal Revisi III, Direktorat Jenderal Bina Marga.

12. Henry Liu, W. B., Kirk, 2007, Improving Freezing and Thawing Properties of Fly Ash Bricks, Jurnal, World of Coal Ash (WOCA), Lexington.

13. Pemerintah Republik Indonesia, 2006, Peraturan Pemerintah Nomor 39 Tahun 2006 Tentang Tata Cara Pengendalian dan Evaluasi Pelaksanaan Rencana Pembangunan.

14. Pemerintah Provinsi Jawa Barat, 2015, Standar Biaya Belanja Pemerintah Provinsi Jawa Barat Tahun Anggaran 2015.

15. Saodang, H., 2005, Perancangan Perkerasan Jalan Raya, Nova, Bandung.

16. Sinaga, I., 2002, Penggunaan Limbah Hancuran Genteng Sebagai Alternatif Agregat Kasar pada Campuran Hot Rolled Asphalt, Jurnal Teknik Sipil, Universitas Kristen Maranatha, Bandung.

17. Sukirman, 2008, Beton Aspal Campuran Panas, Edisi ke-2, Penerbit Yayasan Obor Indonesia, Jakarta.

18. Universitas Kristen Maranatha, 2001, Pedoman Praktikum Bahan Perkerasan Jalan, Laboratorium Transportasi Fakultas Teknik Jurusan Teknik Sipil, Bandung.

19. Yamamoto, 2006, Fly Ash as a Cement Mixture, Public Communications Group Tokyo, Jepang. 